\title{
THE PENDING ARBITRATION TREATY WITH GREAT BRITAIN.
}

Four general arbitration treaties have been negotiated between the United States and Great Britain: the Olney-Pauncefote Treaty of 1897, the Hay-Durand Treaty of I904, the existing arbitration convention negotiated by Secretary Root and Ambassador Bryce, and signed in I908, and the pending Arbitration Treaty negotiated on the enlightened initiative of President Taft by Secretary Knox and Ambassador Bryce, signed August 8, I9II. ${ }^{1}$

The first of these conventions, after being amended by the Senate, failed to secure the two-thirds majority necessary to obtain the advice and consent of that body. The second, after being amended by the Senate so as to require the concurrence of the Senate in the negotiation of the terms of submission or compromis in each particular case, was withdrawn from further consideration by President Roosevelt. However, it was substantially reimbodied, with the acceptance of the Senate amendment, in the convention of 1908 which was duly advised and consented to by the Senate, and which is now in force. The pending treaty, is now before the Senate for its advice and consent. ${ }^{12}$

The Olney-Pauncefote Convention of 1897 provided for the constitution of three separate courts of arbitration, consisting of three, five and six members, respectively. The first two courts were to be composed of "jurists of repute"; while it was provided that three of the members of the third court should be "Judges of the Supreme Court of the United. States or Justices of the

\footnotetext{
${ }^{1}$ For a very informing statement of the genesis and history of the idea of an arbitration treaty between the United States and Great Britain see an interesting article by Doctor Lammasch, President of the Tribunal in the North Atlantic Coast Fisheries Arbitration, entitled "Der Englisch-Amerikanische Schiedsgerichtsvertrag," in Vol. 29, number I, of the Österreichische Rundschau.

${ }^{x_{a}}$ An agreement has been reached to vote upon the treaty and the proposed amendments to the treaty and to the resolution of ratification on the legislative day of March 5th. (See Congressional Record, Vol. 48, No. 45 , p. I8I6.) The fate of the treaty will, therefore, presumably be decided at about the time when this magazine reaches its readers.
}

(388) 
Circuit Court: *** and the other three, *** Judges of the British Supreme Court of Judicature or members of the Judicial Committee of the Privy Council."'2

The two countries agreed to submit to these three arbitral courts, "all questions in difference between them, which they may fail to adjust by diplomatic negotiation."3 Pecuniary claims under one hundred thousand pounds were to go to the first tribunal of three, with provision for an appeal to the second tribunal of five. Pecuniary claims above one hundred thousand pounds were to go directly to the second tribunal. It was provided, however, that "territorial claims," or a pecuniary claim which the second tribunal of five held "necessarily involves the decision of a disputed question of principle of grave general importance affecting the national rights of such party, as distinguished from the private rights whereof it is merely the international representative," should only be decided by the third tribunal of six members, acting by a majority of not less than five to one.

In the case of an award by a less majority, it was provided that there should be "no recourse to hostile measures of any description until the mediation of one or more friendly Powers has been invited by one or both of the High Contracting parties." 4

This treaty, although earnesly recommended both by Presidents Cleveland and McKinley, proved to be too far ahead of the times; and, even after it had been so amended as to be scarcely

\footnotetext{
2 Olney-Pauncefote Treaty, Article VI. It was also provided in Article VIII that in a case which concerned a particular state or territory of the United States, or a British colony or possession, a judicial officer of the state, territory, possession or colony might be appointed.

"This article was amended by the Senate by inserting after "negotiation," the following: "but no difference shall be submitted under this treaty which, in the judgment of either power, materially affects its honor, the integrity of its territory, or its foreign or domestic policy; nor shall the question be submitted whether any treaty once existing continue in force; nor shall any claim against any State of the United States, alleged to be due to the Government of Great Britain, or any subject thereof, be a subject matter of arbitration under this treaty: Provided, That any agreement to submit, together with its formulations, shall in every case, before it becomes final, be communicated by the President of the United States to the Senate with his approval and be concurred in by two-thirds of the senators present, and shall also be approved by Her Majesty the Queen of the United Kingdom of Great Britain and Ireland." Sen. Doc. No. I6r, 58th Cong., 3d Sess., p. 3I.

- Article VI
} 
recognizable, it failed, as above noted, to receive the two-thirds majority vote prerequisite to the Senate's advice and consent. ${ }^{5}$

The meeting of the Hague Conference of 1899 and the adoption by that Conference of a convention for the pacific settlement of international disputes, to which the United States, Great Britain and other leading nations of the world became parties, has naturally exerted a profound influence upon both the substance and the language of the subsequent arbitration treaties of the United States.

In Article IX of the Hague Convention. the signatory powers recommended a Commission of Inquiry "in differences of an international nature involving neither honor nor vital interests, and arising from a difference of opinion on points of fact," $\mathrm{C}$ while, in Article XVI, they recognized arbitration as the most effective and equitable means of settling disputes, where diplomacy has failed, involving "questions of a legal nature and especially $* * *$ the interpretation or application of International conventions." 7

In Article XIX, special provision was made preserving the right to conclude further treaties of arbitration between any two or more signatory powers, "with a view to extending obligatory arbitration to all cases which they may consider it possible to submit to it." 8

It was in accordance with these provisions, that the second general arbitration treaty with Great Britain, the abortive Hay. Durand Convention of I904, was negotiated.

Then came the Second Hague Conference with its general convention for the pacific settlement of international disputes, reaffirming and perfecting the provisions of the first convention, and its Voeu with respect to the creation of a court of arbitral

See Senate Doc. $16 r, 58,3$ rd, for text of the treaty and extracts from the executive journal of the Senate showing the Senate's action thereon. There were some sixteen amendments. Aside from the amendment to article I, quoted supra, note 3, p. 389 , two, entire articles were stricken out by amendments.

-Treaties and conventions, etc., between the United States and other powers, 1776-1909, page 2022.

'Treaties and conventions, etc., between the United States and other powers, 1776-1909, page 2023.

-Treaties and Conventions, etc., page 2023. 
justice; that is, a permanent court composed of a small number of salaried judges who should sit regularly at the Hague, and who should be prepared when duly empowered by general treaty or a special compromis, to administer justice between nations.

In I908 the existing treaty, in substantially the identical terms of the Hay-Durand Treaty, plus the acceptance of the principle that the compromis in each individual case should be submitted to the Senate, was negotiated and ratified.

The jurisdictional provision ${ }^{9}$ of this, the exsting general arbitration convention with Great Britain, reads as follows:

"Differences which may arise, of a legal nature or relating to the interpretation of treaties existing between the two contracting parties and which it may not have been possible to settle by diplomacy, shall be referred to the Permanent Court of Arbitration established at the Hague by the convention of the 29th of July, I899; provided, nevertheless, that they do not affect the vital interests, the independence, or the honor of the two Contracting States, and do not concern the interests of third parties." 10

It is further provided that, in each case, a "special agreement" shall be concluded, defining the matters in dispute, the powers of the arbitrators, procedure, etc., and that, on the part of the United States, this special agreement will be made by the President, by and with the advice and consent of the Senate, while the government of Great Britain reserves the right to obtain the concurrence of the government of any self-governing British dominion, before concluding a special agreement in any way affecting any such dominion. ${ }^{11}$

At the same time that the United States was entering into these general arbitration treaties, it was maintaining its record (with Great Britain), as the world's most frequent suitor at the bar of International Justice. The United States was a party to four of the nine cases submitted to the Hague Tribunal during the first ten years of its existence (April 9, I9or, to April 9, I9I I), including the first case submitted,- the Pius Fund Case;

\footnotetext{
'Article I.

${ }^{10}$ Treaties and conventions, etc., page 814; Senate Document 98, 62nd Congress, Ist Session, page 46.

${ }^{1}$ See Article II.
} 
and in still another case, the Japanese House-Tax Case, the United States agreed to be bound by the Court's decision. ${ }^{12}$

At the same time that the United States has led the way to the Hague Tribunal, it has by no means abandoned its centuryold practice of resorting to special tribunals so constituted as to meet the needs of particular occasions. Since the early nineties, the United States and Mexico have maintained an International Boundary Commission, charged with the duty of deciding boundary questions arising along the Rio Grande, which has successfully handled many important questions. In like manner special tribunals have been resorted to for the settlement of disputes arising along our northern border, notably in the matter of the disputed Alaska boundary in $1903 .{ }^{13}$ And by the recent treaty of January II, I909, the United States and Great Britain have agreed to establish and maintain "an International Boundary Commission of the United States and Canada composed of six commissioners," three appointed by each country, ${ }^{14}$ which has jurisdiction as of course, over "cases involving the use or obstruction or diversion" of boundary waters $;^{15}$ jurisdiction for purposes of examination and report, upon the request of either party, over any question "involving the rights, obligations or interests of either nation in relation to the other, or to the inhabitants of the other along the common frontier between the United States and the Dominion of Canada ;8 and jurisdiction, with the consent of both parties, over "any question or matters of difference arising between the High Contracting Parties involving the rights, obligations or interests of the United States or of the Dominion

${ }^{12}$ These cases were as follows: Ist Case, United States v. Mexico, The Pius Fund Case, decided October I4, I902; 2nd Case, Germany, Great Britain and Italy v. The United States of America, Belgium, France, Mexico, The Netherlands, Sweden and Norway, The Preferential $\Gamma_{\text {reatment Case, decided }}$ February 22, I904; 3rd Case, Great Britain, France and Germany v. Japan, The Japanese House-Tax Case, decided May 22, 1905 (The United States, though not a party, agreed to be bound by the result); 7 th Case, The United States of America v. Great Britain, The North Atlantic Coast Fisheries Case, decided September 6, 1910; 8th Case, The United States of America v. Venezuela, The Orinoco Steamship case, decided October 25, 19 Io.

${ }^{13}$ Treaties and Conventions, etc., page 788 .

${ }^{13}$ Article VII.

${ }^{15}$ Article VIII.

${ }^{18}$ Article IX. 
of Canada, either in relation to each other or to their respective inhabitants."

It was, therefore, not only in the light of a long and varied experience on the part of the United States in the framing of both general and special agreements for arbitration, and particularly for arbitration with Great Britain, but also in the light of our unequalled record as an international litigant "in all courts," that President Taft initiated the negotiations leading up to the pending treaties by expressing in several public addresses, his willingness to negotiate general treaties of arbitration, broader in their scope than those which great nations had hitherto been willing to make, and Secretary Knox undertook the delicate task of giving concrete form to this inspiring suggestion. ${ }^{18}$

The preamble of the pending treaty with Great Britain ${ }^{18 a}$ recites the one hundred years of peace since $18 \mathrm{I}_{4}$; the adjustment of many controversies through arbitration, so that "now for the first time there are no important questions of difference outstanding between" the two countries; and sets forth the determination of the High Contracting Parties that no "future differences" shall make trouble between them. It further recites that the parties have determined "to conclude a treaty extending the scope and obligations of the policy of arbitration adopted in their present arbitration treaty of April 4, Igo8, so as to exclude certain exceptions contained in that treaty and to provide means for the peaceful solution of all questions of difference which it shall be found impossible in future to settle by diplomacy." * * *19

${ }^{17}$ Article $X$.

${ }^{18}$ See President Taft's Addresses: Before the American Peace and Arbitration League, New York City, March 22, Igro; at the Banquet of the American Society for the Judicial Settlement of International Disputes, Washington, December 17, 1910; at the dinner of the Pennsylvania Society of New York City, January 2r, I9II ; before the American Society for Judicial Settlement of International Disputes, Cincinnati, November 7 , IgIr. See, also Sir Edward Grey's remarks in the British House of Commons, quoted at some length in Mr. Snow's valuable article, "Legal Limitation of Arbitral Tribunals" in 60 Univ. of Penna. Law Review, I53 (December, I9II).

${ }^{28}$ aThe text of the pending treaty with France is practically identical with that of the English treaty. It is believed that all differences in the two texts which are of any importance are incidentally noted in the present article.

${ }^{19}$ For text of the pending treaty see Senate Doc. 98, 62nd Cong., Ist Sess., p. 47-50; American Journal International Law. Supplement, vol. 5, p. 253 . 
In accordance with the terms of this preamble, the treaty proceeds, in seven articles, to provide for the pacific adjustment of all future differences between the two countries which do not yield to the regular processes of diplomacy.

Secretary Knox has summarized the provisions of the treaty as dividing all differences into two classes:

"Those which in their nature are arbitrable and those which are not. As to those which are arbitrable, it is provided that they shall be arbitrated. As to those which are not arbitrable, it is provided that they shall be the subject of deliberate inquiry, investigation, and advice."20

We are constantly told, and most people believe, that there are some questions which, at least under present conditions, no nation can arbitrate. It is on account of these questions, that matters affecting "the vital interests, the independence, or the honor of the two contracting states" have been excepted in most arbitration treaties, and are excepted in our present treaty with Great Britain.

These exceptions are not only so vague and elastic as to place no limits upon the parties to the treaties, except those imposed by the constience of their respective peoples as manifested through their governments, but they are essentially illogical. It is not only impossible to say what any given nation at any given time will regard as affecting its honor or vital interests, but, even if it were possible to define these terms, the limits so prescribed would not be the generally admitted limits of judicial procedure.

It is believed that there are comparatively few who have studied the subject, who would, at the present time, be willing to maintain that the importance of a principle, or the magnitude of the interests which may be involved in any question, are proper tests as to whether or not that question should be submitted to arbitration, provided an adequate tribunal can be found. It is

${ }^{20}$ Secretary Knox's Speech at Cincinnati, Nov. 8, IgIr. Senate document No. 298, 62nd Congress, 2nd Session, page 4. Frequent reference will be made to this lucid and authoritative exposition of the provisions of the treaty. 
not the importance of the problem, but its nature, which makes it arbitrable or non-arbitrable.

The great service which is rendered by the present treaty is that, for the first time, it is believed, in history, two great nations have expressly taken cognizance of this essential difference between things which can be determined by the methods common to all courts, whether municipal or international, and those which cannot; and have provided that all questions which are susceptible of judicial treatment, shall be decided by an international court. This fundamental conception, which underlies the whole scheme of the treaty, is thus stated by Secretary Knox:

"The treaties rest upon the theory that arbitration is a judicial function and represents a principle, namely, the application of law and judicial methods to the determination of international disputes, and that a case to be one for arbitration must involve differences susceptible of being decided by the application of acknowledged principles of justice-that is to say, a justiciable difference." 21

It remains to consider how the general principle is worked out in the treaty for everyday use. The vital jurisdictional clause of the treaty, which defines what is arbitrable, is the first clause of Article I, which reads as follows:

"All differences hereafter arising between the High Contracting Parties, which it has not been possible to adjust by diplomacy, relating to international matters in which the High Contracting Parties are concerned by virtue of a claim of right, made by one against the other under treaty or otherwise, and which are justiciable in their nature by reason of being susceptible of decision by the application of the principles of law or equity, shall be submitted to the Permanent Court of Arbitration established at the Hague by the convention of October I8, I907, or to some other arbitral tribunal, as may be decided in each case by special agreement, which special agreement shall provide for the organization of such tribunal if necessary, define the scope of the powers of the arbitrators, the question or questions at issue, and settle the terms of reference and the procedure thereunder."

The importance of this provision justifies a somewhat detailed examination of its various phrases with a view to considering how far they successfully embody the principle of the application of the judicial function to international differences

${ }^{2}$ Senate Document No. 298, 6and Congress, and Session, page 4. 
susceptible of decision "according to the principles of justice," and at the same time how successfully they guard against certain practical objections which must be considered in framing an agreement of this character.

Before any difference can be submitted to arbitration under the treaty, it must qualify under the following heads: ${ }^{22}$

r. It must be "hereafter arising."

It is this provision, in connection with the recital in the preamble, to the effect that there are "no important questions of difference outstanding" between the two countries, which is relied on to exclude from the scope of the treaty all questions involving the liability of the United States to respond internationally for the obligations of certain of the bonds of some of the southern states, issued during the period of reconstruction, and which have been repudiated. It is submitted that, under the circumstances, and in connection with other provisions of the treaty, these provisions sufficiently guard against any liability on the part of the United States on these bonds. ${ }^{23}$

2. It must be "between the High Contracting Parties."

This provision, as well as numbers four and five below, may well have a bearing in connection with the question of the -reconstruction bonds. ${ }^{24}$

${ }^{22}$ See analysis of the first clause of Article $I$, in President Taft's address at the Methodist Conference, Ocean Grove, N. J., August 15, I9II, and also in Secretary Knox's Cincinnati address, November 8, rgrr.

${ }^{23}$ See President Taft's address to the Grand Army of the Republic, Rochester, N. Y., Auguut 23, I9II. See also President Taft's Cincinnati address, November 7, I9II, where he said: "Well, the language of the treaty is 'in all cases hereafter arising' which excludes these bonds. Therefore, if anybody is sensitive on that point, he has no need to fear the treaty." Proceedings of the American Society for the Settlement of International Disputes, 19II, page 20. Compare, in this connection, the language of the Boundary Convention between the United States and Mexico of 1884 which recites that: "to avoid differences which may arise through the changes of channel to which these rivers are subject through the operation of natural forces

In commenting on this language the Presiding Commissioner of the International Boundary Commission in his decision rendered in the Chemizal Case, May 15, I9Ir, said: "While it is perfectly true that the Convention was to be applied to disputes which might arise in the future it nowhere restricts these difficulties to future changes in the river." [Minutes of the meetings of the International Boundary Commission, June Io and and 15 , I9II, page 23.]

${ }^{24}$ See the language of the Senate Amendment to the Olney-Pauncefote Treaty, [Article I], supra, note 3. 
3. It must be one which "it has not been possible to adjust by diplomacy."

4. It must be a difference "relating to international matters."

5. It must be a difference in which the High Contracting Parties are concerned "by virtue of a claim of right made by one against the other under treaty or otherwise." 24a

6. Finally, such a difference must be "justiciable in their [its] nature by reason of being susceptible of decision by the application of the principles of law or equity."

"Justiciable" is defined by Webster as "liable to trial in a court of justice; subject to jurisdiction; judicable." It would seem that there could hardly be a more apt word to express the precise idea desired; and, so far as noted, there has been no criticism of the word "justiciable" per se, except, perhaps, that it is new in connection with international matters.

Some discussion has, however, arisen as to the meaning of the expression, "principles of law or equity," particularly the word "equity." Three interpretations of these words have been suggested in the Senate.

In the first place, Senator McCumber has argued that, as between the United States and England, the words "law or equity" have a definite and technical legal meaning, namely, the rules of decision which prevail in the law courts and the Chancery courts of the two countries, and that there can be no question that this is the meaning which must be given to the words in the treaty with Great Britain. ${ }^{26}$ It is further argued that it is a matter of common knowledge that the treaty with Great Britain was negotiated first, and that with France, in identical language, afterwards ${ }^{25}$ and that, in accordance with the well-known legal principle, the language of the treaty with Great Britain having been adopted in the French treaty, the

\footnotetext{
${ }^{2 t_{2}}$ See colloquy between Senator Burton and Senator Cummins during Senator Burton's speech February 6, as to the meaning of the words "claim of right:" in Congressional Record, February 12, vol. 48, No. 5I, at p. 2090. See also Senator Lodge's statement on this point, Congressional Record, p. 1849.

${ }^{25}$ The two treaties were signed on the same occasion, the treaty with England being signed first.

${ }^{20}$ See speech of Senator McCumber in the Senate, January 22, 1912, Congressional Record, vol. 48, No. 33, page 1280 , at 1288 .
} 
construction given to this language in the English treaty must be deemed to have been accepted also.

A second suggestion is that of Senator Rayner, who points out that while courts of equity in the technical sense of English law are unknown to French jurisprudence, the principles of equity were imported into French law from the law of Rome; and that the words "law or equity" in the French treaty must be deemed to cover the entire field of French law, just as in the English treaty they cover the entire field of English law; and that the expression is, therefore, intended in both treaties to cover all matters justicable under the legal systems of the High Contracting Parties, respectively. ${ }^{27}$

The majority of the Senate Committee on Foreign Affairs takes a different and more extended view of the scope of the phrase in question. They regard the language of the treaty as "very large and general and somewhat indeterminate;" and, in view of the non-existence in French law of the technical "Equity" of the English law, they are obliged "to construe the word 'equity' in its broad and universal acceptance as that which is 'equally right or just to all concerned; as the application of the dictates of good conscience to the settlement of controversies." " And they add: "It will be seen, therefore, that there is little or no limit to the questions which might be brought within this article, providing the two contracting parties consider them justiciable."28

It is submitted with deference that, while, of course, the two contracting parties could, by common consent, as a practical matter, consider anything whch they saw fit justiciable, because they could, by consent, place any interpretation which they saw fit upon any word in the treaty, nevertheless the expression "justiciable $* * *$ by reason of being susceptible of decision by the application of the principles of law or equity," cannot properly be given such a latitudinarian construction as is suggested by the majority of the Senate Committee. The

\footnotetext{
${ }^{27}$ See Senator Rayner's minority views, Senate Document 98, 62nd Congress, Ist Session, pages 19-20; see also his speech in the Senate, Con. gressional Record, January I6, Ig12; vol. 48 , No. 28 , page I027, at page ro28.

${ }^{23}$ Senate Document 98, 62nd Congress, Ist Session, pages 4 and 5.
} 
United States has used the expressions, "according to justice and equity" and "according to the principles of justice and equity," in her arbitration treaties for more than one hundred years, to define the principles by which arbitrators should be guided in rendering their decisions; ${ }^{29}$ and wherever it has been suggested that this expression gave to the arbitrators unlimited discretionary authority, this suggestion has been negatived. ${ }^{30}$ If the words "justice and equity" have not been held to have the broad and indefinite meaning ascribed to them by the majority of the Senate Committee, much less, it would seem, could such an interpretation properly be placed upon the words "law or equity," noscitur a sociis.

It is submitted that, while there is much force, from a technical standpoint, in the argument that the words should be given the peculiar meaning which they have in English law, nevertheless, on the whole, bearing in mind that it is not only

$\approx$ The following arbitration treaties of the United States, given in their chronological order, use these expressions in prescribing the rules by which the arbitrators are to be guided: Great Britain, treaty of Amity, Commerce and Navigation (Jay Treaty), November 19, 1794, Article VI; Great Britain, Convention respecting Fisheries, Boundary, and the Restoration of Slaves, October 20, I818; Great Britain, Claims Convention, February 8, 1853; Costa Rica, Claims Convention, July 2, I860; Great Britain, Treaty for Settlement of Claims with the Hudson's Bay Company, etc., July I, 1863; Great Britain, Treaty of Washington, May 8, I871, Article XII, (Claims arising during the Civil War aside from the Alabama Claims). The following treaties and conventions use language the same or substantially the same as the Seventh Article of the Jay Treaty with Great Britain which reads, "according to the merits of the several cases and to justice, equity, and the laws of nations:" Spain, Treaty of Friendship, Boundary, etc., October 27, 1795, Article XXI, (Claims arising during the war between Spain and France); Denmark, Claims Convention, March 28, I830; Peru, Claims Convention, January 12, 1863; Mexico, Claims Convention, July 4, 1868. [See Treaties and Conventions of the United States, etc., passim; see also Argument of the United States, Orinoco Steamship Company Case before the Hague Tribunal, page II7, Note.]

${ }^{20}$ See the decision of the Hague Court in the Orinoco Steamship Company Arbitration between the United States and Venezuela, where the Court held that a provision requiring arbitrators to "decide all claims upon a basis of absolute equity without regard to objections of a technical nature or of the provisions of local legislation," did not "invest the arbitrators with discretionary powers." American Journal of International Law, January, I9II, vol. $\forall$, page 230 at page 233. See also "Orinoco Steamship Company Case before the Hague Tribunal," Ibid, pages 39-50. See the interesting remarks of Commissioner Frazier in the case of the Sir William Peel, Report of Robert S. Hale, Agent, House Executive Document I, Part I, 43rd Congress, Ist Session, pages 246-247 [Foreign Relations of the United States, I873, vol. 3]. 
"a treaty we are construing," but a treaty which is intended as a model for treaties with all the civilized nations of the world, ${ }^{31}$ this interpretation is somewhat too provincial and Anglo-Saxon. In any event it would not be safe to count upon a tribunal, composed as any tribunal constituted by the United States and France under the Hague rules, is apt to be constituted, giving such an interpretation to the treaty; nor, does such a narrow interpretation appear necessary in order to render the treaty practical and safe.

In a passage already quoted, Secretary Knox paraphrased the treaty words in question by the expression: "susceptible of being decided by the accepted principles of justice;"32 and it would seem that this is, in brief, all that the treaty language means, and all that the United States could fairly ask that it could mean, if it is hoped to negotiate similar treaties with countries where the English system of law does not prevail; $i$. e., with all the rest of the world except England. It is submitted that the "accepted principles of justice" mean the principles of justice as administered in courts of law acknowledged by the parties to the agreement. This is substantially the interpretation placed upon the words of Senator Rayner, and is, it is believed, about as definite a phraseology as it would be possible to obtain, at this time, in a treaty with any country except Great Britain. Doubtless it would be possible to negotiate a treaty with Great Britain in which it was expressly stated that the words "law" and "equity" were used in the technical sense of Anglo-Saxon law, but doubtless, too, it is unnecessary to insert such a stipulation in a treaty with Great Britain.

In any tribunal constituted by Great Britain and the United States, and, particularly, in any Joint High Commission constituted under Article II of the pending treaty, the principles of Anglo-Saxon law are likely to receive due consideration; and it is highly desirable, if possible, to have a uniform phrase-

${ }^{31}$ See report of the majority of the Senate Committee, Senate Document 98,6 and Congress, Ist Session, page 8 . See also President Taft's Cincinnati Address, etc.

" See President Taft's Address at Mountain Lake Park, Aug. 7, IgrI, where he speaks of "law and equity, as those are understood in law and in international law." 
ology in such treaties for many reasons: among others, because, in the opinion of the writer, it is desirable that the peculiar principles of Anglo-Saxon law should have a fair chance, by way of the survival of the fittest, to leave their impression upon the international law of the world.

The jurisdictional clause of the treaty seems, therefore, to embody, as precisely as is reasonably possible in an instrument of this character, the fundamental conception of the treaty, that all questions which are arbitrable shall be arbitrated; and it also appears adequate to meet the practical difficulties which have suggested themselves in the past, ${ }^{33}$ or have been suggested in connection with the pending treaty. It is believed that any further amplification of this article, such as that originally suggested $^{-}$in the minority report presented by Senator Root, ${ }^{34}$ is unnecessary, and that Senator Root's resolution, amended as proposed by Senator Bacon, ${ }^{35}$ so as to recite a number of specific matters which are not deemed arbitrable, would become positively dangerous because of the principle expressio uniis. ${ }^{36}$

It will be observed that the treaty provides that justiciable questions "shall be submitted" to the Hague Court, "or to some other arbitral tribunal as may be decided in each case by special agreement, which special agreement shall provide for the or-

${ }^{33}$ See Senate Amendment to Article I of the Olney-Pauncefote Treaty, supra, note 3 .

"Senator Root's proposed substitute for the Resolution of Ratification provides: "That the Senate advises and consents to the ratification of the said treaty with the understanding, to be made a part of such ratification, that the treaty does not authorize the submission to arbitration of any question which depends upon or involves the maintenance of the traditional attitude of the United States concerning American questions, or other purely governmental policy." (See Doc. 98, 62nd Cong., Ist Sess., p. 27.)

${ }^{25}$ Senator Bacon's amendment to Senator Root's resolution provides as to this point: "That the Senate advises and consents to the ratification of the said treaty with the understanding, to be made a part of such ratification, that the treaty does not authorize the submission to arbitration of any question which affects the admission of aliens into the United States, or the admission of aliens to the educational institutions of the several states, or the territorial integrity of the several states or of the United States, or concerning the question of the alleged indebtedness or monied obligation of any state of the United States, or any question which depends upon or involves the maintenance of the traditional attitude of the United States concerning American questions. commonly described as the Monroe Doctrine, or other purely governmental policy." (Ibid, p. 28.)

"See Letter of Senator Williams, Advocate of Peace, January, Igra, page 7. 
ganization of such tribunal, if necessary," etc. This is a departure from the existing arbitration convention, which provides merely for reference to the Hague Court; but it is believed to be a departure which is amply justified by the practical experience of the United States. As will be remembered, as recently as I903, immediately after the successful appeal to the Hague Court by the United States and Mexico in the Pius Fund Case, it was found necessary, if the Alaska Boundary Controversy was to be arbitrated at all, to resort to a special tribunal along lines suggested by the Olney-Pauncefote Treaty, namely, composed of "six impartial jurists of repute, *** three to be appointed by the President of the United States and three by His Britannic Majesty."37 Whatever may be the theoretical objections to a tribunal so constituted, it worked well in practice in a very trying situation.

This was not the first instance in which the United States and Great Britain have had an object lesson in the advantages to be derived from having arbitrators familiar with the language, institutions and laws of the two countries, even though handicapped by citizenship in one or the other of the countries litigant. ${ }^{38}$ In fact it is submitted that the time is fast coming, if it is not at hand, when the United States and England can entrust to such a court as the "Territorial" Court of six members, chosen from the judiciary of both countries, provided for in the Olney-Pauncefote Treaty, and justiciable questions which could arise between them, in the confidence that whatever the judgment suffered from unconscious national bias, would be more than made up for by the competence of the members of the court, in the language, laws, and ideals of the two countries; for it must be remembered that it has been demonstrated in various international arbitrations, that ignorance is as much an enemy to justice as prejudice;

${ }^{37}$ Treaties and Conventions, etc., page 788.

${ }^{38}$ See, for example, the selection of Joshua Bates, an American citizen residing in England, as the Umpire of the United States and British Claims Convention of 1853 after ex-President Van Buren had declined to serve. Moore's History of International Arbitration, page 398. It is interesting to note that Secretary Seward said of this Commission that it "had the prestige of complete and even felicitous success." [Mr. Seward to Mr. Reverdy Johnson, November 27, 1868; Diplomatic Correspondence, 1868, Pt. I, page 380 ; cited, Moore, page 39r.] 
and, moreover, ignorance is by no means incompatible with prejudice.

These observations are not intended in any way to derogate from the generally accepted view that the spirit of the rule that no man should be a judge in his own case applies to exclude nationals from courts of arbitration; but, it is submitted, there may be an exception to this general principle in the case of two nations like the United States and Great Britain, having common language, laws, and institutions, which are not easily understood by judges, no matter how eminent, trained under a different system; nations, moreover, which enjoy the advantage of having more perfectly developed than perhaps any other countries, the conception of a judiciary independent of the executive, from whose members judges can be drawn who, while they cannot, being human, be expected to be perfectly exempt from national bias, may reasonably be deemed to represent the minimum of bias which can be obtained so long as nationals are allowed to sit upon an international tribunal. ${ }^{39}$

The second clause of Article One provides that Articles 27 to 90 of the Hague Convention for the pacific settlement of international disputes (the articles relating to arbitration proper) except Articles 53 and 54, which empower the arbitral tribunal in certain instances to frame the compromis of submission, "shall govern the arbitration proceedings to be taken under this treaty," so far as applicable.

The third clause of the article provides, in the following language, substantially copied from the existing Convention, for the participation of the Senate in the framing of the compromis:

"The special agreement in each case shall be made, on the part of the United States, by the President of the United States, by and with the advice and consent of the Senate thereof, His Majesty's Government reserving the right before concluding a special agreement in any matter affecting the interests of a self-governing dominion of the British Empire, to obtain the concurrence therein of the government of that dominion."

$\because$ See American Journal of International Law, vol. V, page 63 ; Columbia Law Review, vol. XI, page 508 . 
Article I, therefore, provides judicial machinery for judicial questions. Article II provides entirely different machinery for the handling of semi-judicial or non-judicial questions. It provides for the creation of a Joint Commission of Inquiry to which, on request of either party, justiciable questions may be referred for investigation before arbitration, and also non-justiciable matters. Any such reference may be delayed for a year at the request of either party in order to afford time for further diplomatic discussion.

The Commission is to be constituted ad hoc as occasion arises, in the following manner:

"Whenever a question or matter of difference is referred to the Joint High Commission of Inquiry, as herein provided, each of the High Contracting Parties shall designate three of its nationals to act as members of the Commission of Inquiry for the purposes of such reference; or the Commission may be otherwise constituted in any particular case by the terms of reference, the membership of the Commission and the terms of reference to be determined in each case by an exchange of notes."

Clause three provides that Articles 9 to 36 inclusive of the Hague Convention (the articles relating to Commissions of Inquiry), shall govern the order and procedure of the Commission so far as applicable.

The majority of the Senate Committee criticize the constitution of the Commission as follows:

"The committee ventures to think that some of the changes here made from The Hague provisions, are not in the direction of an advance, but of a retreat, because they revive the idea of confining membership in the Commission, if insisted upon by either party, to nationals instead of to wholly disinterested outsiders, which is the conception of The Hague convention.

So far as the treaty with Great Britain is concerned, the suggestions which have already been made with regard to the property of leaving it open, as between the United States and Great Britain, to constitute a tribunal wholly of nationals, apply with even greater force to the Joint High Commission.

In the case of the Joint High Commission, however, the treaty, instead of giving an option to deviate from the Hague 
rules, provides for the appointment of nationals unless it is otherwise specified, leaving the powers free to revert to the Hague rules or to constitute the Commission as they may see fit by special agreement.

The reason for making the appointment of nationals the normal method of constituting the Commission rather than the exception, grows out of the peculiar function assigned to the Commission by Article III, a function entirely unknown to the Commission of Inquiry of the Hague conventions, and which will be discussed later on.

It would seem that the majority of the Senate Committee in a way answer their own criticism when, on the same page of their report, in discussing this particular function of the Commission, they express apprehension at the great power placed in the hands of a commission which "may be composed wholly of foreigners."

The treaty leaves the two countries entirely at liberty to constitute the Commission in accordance with the needs of each situation as it arises; but, in riew of the peculiar and surpassing function of the Commission under Article III, it provides that, in the absence of agreement, the Commission shall be composed of nationals. It is not believed that, under these circumstances, this arrangement constitutes a retreat from the position taken by the United States at the Hague.

It should be noted that, in all cases in which questions are referred to the Joint High Commission for examination, "terms .of reference are to be settled by an exchange of notes." This, of course, means that the terms of reference, in each case, are to be fixed by the executives of the two countries, and does not require the submission of these terms of refierence by the President to the United States Senate.

Article III defines, in greater detail, the functions of the Joint High Commission of Inquiry. Inasmuch as this article is the storm centre of the discussion which has arisen with reference to the treaty, it is here quoted in full:

"The Joint High Commission of Inquiry, instituted in each case as provided for in Article II, is authorized to examine into and 
report upon the particular questions or matters referred to it, for the purpose of facilitating the solution of disputes by elucidating the facts, and to define the issues presented by such questions, and also to include in its report such recommendations and conclusions as may be appropriate.

"The reports of the Commission shall not be regarded as decisions of the questions or matters so submitted either on the facts or on the law, and shall in no way have the character of an arbitral award.

"It is further agreed, however, that in cases in which the parties disagree as to whether or not a difference is subject to arbitration under Article I of this treaty, that question shall be submitted to the Joint High Commission of Inquiry; and if all or all but one of the members of the Commission agree and report that such difference is within the scope of Article I, it shall be referted to arbitration in accordance with the provisions of this treaty." $30 \mathrm{a}$

The discussion which has arisen concerns itself, primarily, with the interpretation of the third paragraph of this article and with the constitutionality of one interpretation which has been placed upon it.

The majority of the Senate Committee construes this paragraph to mean that "a special agreement, coming to the Senate after the Joint Commission had decided the question involved to be justiciable, could not be amended or rejected by the Senate on the ground that, in their opinion, the question was not justiciable and did not come within the scope of Article I." 40 And

${ }^{* a}$ It is interesting to compare this provision with the articles of the Olney-Pauncefote treaty which doubtless suggested it. In the latter treaty - the second tribunal of five could, by a mere majority, decide that any dispute involved an important question of principle. After that the third tribunal of six could only decide the question on the merits finally by a majority of at least five to one.

${ }^{10}$ Senate Document 98, 6and Congress, ist Session, page 5. And the Committee says, further on in its report: "If our right to exclude certain" classes of immigrants were challenged, the question could be forced before a Joint Commission, and if that commission decided that the question was arbitrable, the Senate would have no power to reject the special agreement for the arbitration of that subject on the ground that it was not a question for arbitration within the contemplation of Article I." [Ibid, page 7.] It will be observed that in these passages the majority of the committee do not quiestion, but on the contrary they expressly admit, that questions which the Commission had held to be justiciable just as other questions which had not been submitted to the Commission could only be referred to arbitration by means of a special agreement, to be framed by the President and submitted to the Senate for its advice and consent. The point which they make is that, while the terms of submission would still have to be referred to the Senate, the Senate would be precluded from object- 
they are of the opinion that the paragraph, so construed, works an unconstitutional delegation of the powers of the Senate. ${ }^{41}$

Senator Root, in a minority report presented for himself, Mr. Cullom and Mr.' Burton, appears to assume the correctness of the construction placed upon the paragraph by the majority of the Committee, but takes issue with the Committee upon the question of constitutionality, maintaining that the treaty does not involve any abandonment of the constitutional powers of the Senate. ${ }^{42}$

Senator Burton, while concurring generally in this minority report, submits a special statement of his views in which he joins issue with the majority as to the proper construction of the paragraph, and maintains that the decision of the Joint High Commission on the question of justiciability does not bind the Senate in its subsequent consideration of the compromis. ${ }^{43}$

The questions of treaty construction and of constitutional power here presented are extremely interesting in themselves, as intellectual problems. Their interest is increased by the importance of the document under consideration, and by the ability with which the discussion has been conducted on all sides. But it is submitted that, in so far as the actual working out of the treaty in operation is concerned, these questions are academic rather than practical. It is highly improbable that the Senate would ever be called on to exercise the power of rejecting a compromis on the ground that it relates to a non-justiciable question, even if the treaty is ratified in a form which secures to the Senate that power.

In the first place it will be remembered that, when the question of the justiciability of any matter is referred to the Joint

ing to or amending these treaties on the ground that the question involved was not justiciable, inasmuch as that question would have already been finally passed upon by the Commission in accordance with the provisions of the treaty.

" $\mathrm{By}$ this clause the constitutional powers of the Senate are taken away pro tanto and are transferred to a commission, $* * * * *$ with the last clause of Article III included, the Senate is deprived of its constitutional power to pass upon all questions involved in any treaty submitted to it in accordance with the constitution." [Ibid, pp. 5-6].

2 Ibid, pp. 9-Io.

Ibid, pp. II-I5. 
High Commission, it will be referred under the terms of submission framed by the executive branches of the two governments, and the phraseology of the terms of submission will necessarily have much to do with the finding of the Commission as regards the question of justiciability. Secondly, three of the members of the Commission will be American citizens, ${ }^{44}$ appointed by an American President, and confirmed by the Senate of the United States, ${ }^{45}$ and at least two of these men must unite with all three of the members appointed by Great Britain in order to reach a decision which binds anybody upon the question of justiciability. Thirdly, tentative terms of submission must be agreed on for the arbitration by the executive branches of the two governments, and submitted to the Senate for its advice and consent. As to the requirement that these terms be submitted to the Senate, there is no issue; the only question is as to the power of the Senate to reject or amend on the ground of non-justiciability.

On any theory, the Senate has power to change the terms of submission, and by these amendments, to "determine the character and composition of the tribunal to which the question is to be referred," "or "define the scope of the powers of the

"The Majority report of the Senate Committee says: "It will be seen by the examination of the clause just quoted, that if the Joint High Commission, which may consist of one or more persons, which may be composed wholly of foreigners or wholly of nationals * * * * *." [Senate Document 98, 6and Congress, Ist Session p. 5.] It is Irue that it is theoretically possible for the President of the United States to designate foreigners, although it is believed that it was on account of this very question of justiciability that it was provided that the Commission should normally consist of nationals; but if it is provided that the members on the part of the United States must be confirmed by the Senate, this theoretical possibility becomes negligible, and it is submitted that the majority of the Senate Committee are in error in the statement" that the Commission "may consist of one or more persons," inasmuch as it is provided that "if all or all but one of the members of the commission agree and report," etc; this undoubtedly looks to the normal commission of six and seems to require, in view of the fact that it must be a joint commission in which both countries are equally represented, at least four members. [See address on the arbitration treaties by Albert E. Pillsbury, Boston, Mass.. December I4, IgIr.]

${ }^{45}$ The treaty is silent as to whether or not the members of the Commission must be confirmed by the Senate. But the President has repeatedly announced his willingness that provision should be made for confirmation by the Senate in the resolution of ratification. [See President Taft's and Secretary Knox's Cincinnati address.] It is so provided in the resolution advising and consenting to ratification presented by Senator Lodge. 
arbitrators and the question or questions at issue."46 And this power, used in perfect good faith and without any intention to question the finality or the Commission's decision as to the justiciability of any matter, in practice, it is submitted, gives the Senate such a control over the matter to be arbitrated, as to make the question of the absolute power of the Joint High Commission to bind the Senate on the question of justiciability, very largely academic.

Moreover, so far as the English treaty is concerned the procedure on the side of Great Britain must also be considered. The British Government reserves the right, "before concludng a special agreement in any matter affecting the interests of a selfgoverning dominion of the British Empire, to obtain the concurrence therein of the Government of that dominion." 47 This provision is absolutely on a par with the provision for obtaining the advice and consent of the United States Senate. It is believed, as a practical matter, that there is little danger that the government of Great Britain, in view of the very large powers which England is accustomed to concede in matters of this character to her self-governing dominions, will be likely to contend for any unduly restricted construction of the Senate's powers of amendment. The same consideration would undoubtedly affect the government of France, where certain kinds of treaties are subject to legislative approval.

However, the question of treaty construction involved in paragraph III and the question of constitutional power are extremely important in principle and as matters of sentiment, and have, perhaps, received more attention than all other questions suggested by the treaty combined.

In Senator Burton's statement of his individual views he sets forth his understanding of the paragraph as follows:

"This clause provides that in cases in which the Parties disagree (that is, the executive branches of the two governments) as to whether or not a difference is subject to arbitration under Article I of this treaty, that question shall be submitted to the Joint High

\footnotetext{
* Senator Burton's Minority Views, Senate Document 98, referred to above, p. 13 .

Paragraph three, Article I. See supra, p. 389 .
} 
Commission of Inquiry, and if all, or all but one, of the members of the Commission agree and report that such difference is within the scope of Article I, it shall be referred to arbitration (that is, the administrative branches of both governments shall take the steps prescribed) in accordance with the provisions of this treaty."

He explains what he understands these steps to be as follows :

"The next step in the proceedings would be, so far as the administratiye branch of this government is concerned, to enter into a special agreement of arbitration, as provided for in Article I, referring the questions in controversy to a tribunal of arbitration. The special agreement would then go to the Senate for its advice and consent." 48

So far, it will be perceived, there is no difference between the procedure outlined by Senator Burton and as understood by the majority of the Committee. But, according to Senator Burton, in passing upon the special agreement as submitted, "the rights and the duties of the Senate are identical, whether the question is referred to that body by the administrative branch in the first instance, or after the decision of the Commission provided for in Article III." 49

Just what Senator Burton believes the rights of the Senate to be in either case is placed beyond doubt when he says, a little further on:

"In such a case, as in every other case, it would be within the power of the Senate to refuse its advice and consent to the special agreement, but it would be contrary to its treaty obligation."

In other words, Senator Burton maintains that the decision of the Joint High Commission as to the question of justiciability is no more binding upon the Senate than the decision of the President in framing a submission and sending it to the Senate without reference to the Commission.

In his address at Cincinnati, November 8, IgIr, already referred to, Secretary Knox lends the weight of his authority

Ibid, page I2.

'Ibid, page I2. 
to the construction advocated by Senator Burton. ${ }^{50}$ And the President himself, who, in his earlier addresses, had apparently assumed that the decision of the Commission would be binding on both countries with no locus ponitentiae, seems to have accepted Secretary Knox's view. ${ }^{51}$

In full view, however, of the construction placed upon the treaty by the Secretary of State, another distinguished lawyer and member of the Senate Committee on Foreign Affairs, Sena-

${ }^{20}$ Secretary Knox states his understanding of the procedure under the treaty in the following language: "Therefore, although in the pending treaties the executive branches of the governments concerned agree to the bound by the decision of the Commission as to the arbitrability of a question upon which the executive branches do not agree, this decision is subject to the approval of the self-governing colonies of Great Britain, if the question affects them, and to the approval of the Senate of the United States, and, in certain cases, the Senate and Chamber of Deputies of France, to whom the right of approval is expressly reserved in each case. Every agreement to arbitrate must go to the Senate for its approval. There can be no arbitration without its approval. An agreement to arbitrate goes to the Senate for its approval either because the executive branches of the two countries concerned in the difference agree that the difference is one for arbitration or because, failing to so agree, the Commission of Inquiry reports that it is such a difference."

"How can the Senate's power over the agreement be less if it goes to the Senate after the Commission's report that it presents an arbitrable question than if it had gone there because of the opinion of the executive branches of both governments to the same effect?"

"If the two governments agree that the difference is arbitrable they make an agreement to arbitrate it and it is sent to the Senate for its approval. If the two governments cannot agree that the difference is arbitrable that ends the matter until the Commission reports, and if its report is that the difference is arbitrable an agreement is made to abitrate it and the agreement is sent to the Senate for approval just as if no such question had been raised, and the Senate deals with it with unimpaired powers." [Senate Document 298, 62nd Congress, and Session, page 8.]

${ }^{31}$ See the following excerpts from President Taft's addresses concerning the treaty:

"*** The Foreign Relations Committee ****** has stricken out the third clause vesting the Commission of six Commissioners, three from each side, with the power to determine whether differences are arbitrable within the meaning of the first section, and to bind both countries when the vote is five out of six in the Commission to the acceptance of a judgment by arbitration upon such issue." [Address at the Methodist Conference, Ocean Grove, New Jersey, August 15, 1911.]

"If so, and five out of six members of the commission decide that it is justiciable and so arbitrable under the first clause then both parties are bound by that decision $*_{*} *_{*} *_{\text {but }}$ the main and chief objection, if I understand it, to the- treaty is that the Senate cannot agree to abide the judgment of a Joint High Commission like this as to whether a difference between the two countries comes under the description contained in the first clause and is, therefore, arbitrable; by doing so it is said the Senate will in some way part with the power conferred upon it by the constitution and which it is forbidden to delegate. $* * * * * *$ How much real risk is 
tor Rayner, filed a minority report urging the ratification of the treaties without amendment, but expressing his agreement with the construction which the majority of the Senate Committee had placed upon the third paragraph of Article III. ${ }^{52}$

The question at issue appears largely to turn upon the interpretation which should be given to the word "Parties" in the first line of the paragraph, which reads: "In cases in which the Parties disagree." * * * * *

When Senator Burton comes to construe this clause, he says: "This clause provides that, in cases in which the Parties disagree (that is, the executive branches of the two governments) * * * * *." And in Secretary Knox's Cincinnati speech, he says: "In the pending treaties the executive branches of the governments concerned agree to be bound by the decision of the Commission * * * *."

run by the Senate in consenting that five-sixths of the Commission may decide a question of construction of the treaty?" Address at Rochester, N. Y. August 23, I9I I.

"Now, under the first clause, the Senate must concur in a special agreement defining the question to be arbitrated and probably-Mr. Knox thinks certainly - the Senate has the power to fail to consent even after the Joint High Commission has acted: the Executive is bound. The Senate may still refuse." Cincinnati, Address, p. I2. - Proceedings of Society for Judicial Settlement of International Disputes.

See colloquy between Senators Cummins and McCumber during Senator McCumber's speech in the Senate, January 22, I912. Congressional Record, vol. 48, No. 33, page 1280, at 1283 .

"Senator Rayner states his conclusions in the following language: "In reference to this point in the majority report, that the decision of the Commission is final, and that after the Commission has decided the question to be justiciable that the treaty could not be amended or rejected on the ground that the treaty is not justiciable, it seems to me that the opinion that the majority of the Committee has reached is correct."

Speaking of the question of authority, Senator Rayner states: "Senator Burton, in this admirable presentment that he has made, is supported by the very high authority of Secretary Knox who construes the treaty in a similar way, and also by Professor Moore of Columbia University who is recognized as one of the highest authorities if not the very best on this and kindred subjects." Senator Rayner refers here to an excerpt from an article of Professor Moore's in the "Independent" of August I7, IgII, which had been quoted in Senator Burton's minority report where Professor Moore says: "for in no case can a question be arbitrated under the pending treaties without the concurrence of the Senate and its approval of the terms of reference." [Senate Document 98; also "Independent," Aug. I7, Igrr.] Query, whether by this general language at that early date, before the present issue had been raised by the Senate Committee in its majority report of August 18th, Professor Moore was intending to express any opinion upon the question as to whether or not the Senate would be precluded upon the question of justiciability? 
Now this is certainly not the normal meaning of the word "Parties" in any treaty, nor, it is submitted, is it the usual meaning of the word in this treaty. The expression, "the High Contracting Parties," is used eight times in the treaty and the word "Party" or "Parties" is used three times more, including the present instance; and it is submitted that in every case the expression, "the High Contracting Parties," refers to the two nations who are entering into the treaty, and the word "Party" or "Parties" refers to the two litigants in some particular controversy, and in none of these cases (unless it be the present instance), is the expression or the word used for the purpose of designating the executive branches of government as distinguishd from government as a whole. ${ }^{53}$

It is submitted that, under these circumstances, if the word "Parties" is to be construed as meaning "executive branches of the government" in the present instance, a clear case for this peculiar usage should be made out. It is believed that those who construe the word "Parties" as meaning the executive branches of the government, rely largely on the practical situation which exists when a disagreement takes place. In practice, such a disagreement must arise, as a matter of fact, between the two executive branches, when it is proposed by one side or the other to prepare a compromis to submit some question to arbitration. But query: Whether this situation is really very unusual? All

"The expression "High Contracting Parties" is used in the following instances: Article I, "All differences hereafter arising between the High Contracting Parties $* * * * *$ in which the High Contracting Parties are concerned." Article II: " * * *** The High Contracting Parties further agree to institute *** a Joint High Commission of Inquiry * * * each of the High Contracting Parties shall designate three of its nationals to act as members of the Commission of Inquiry." Article IV: “**** And the High Contracting Parties agree to adopt such legislation * * * " Article V: "** * All reasonable and necessary joint expenses $\dot{*}^{*} * * *$ shall be paid in equal moieties by the High Contracting Parties." Article VI: "This treaty shall supersede the arbitration treaty concluded by the High Contracting Parties on April 4, Ig08.". Article VII: “**** it shall remain in force continuously unless and until terminated by twenty-four months written notice given by either High Contracting Party to the other."

The word "Party" or "Parties" is used only in the Second, Third, and Fourth Articles. Article II: " $* * *$ provided, however, that such reference may be postponed ****** if either party desires such postponement;" Article III: "It is further agreed, however, that in cases in which the Parties disagree"; Article IV: **** and each party is entitled to appoint an agent." 
disagreements between governments must, of necessity, arise, internationally speaking, between the executive branches, since nations speak only through their foreign offices, and most disagreements do, in fact as well as in theory, arise between the executive branches. Therefore, it may be asked whether the actual situation to which the paragraph in question refers is sufficient to require the word "Parties" to be interpreted "executive branches." If it does not, then it is submitted that the whole interpretation founded upon this assumption falls to the ground; for there does not seem to be anything in the language of the rest of the paragraph to require, or even to indicate, such an interpretation.

The last line in the paragraph, upon which reliance is also placed in this connection, reads that when the Joint High Commission has reported that any question is justiciable, "it shall be referred to arbitration in accordance with the provisions of this treaty." It is admitted that this means that, in this case, as in other cases, the executive branches of the two governments must proceed to frame a compromis which must be submitted to the Senate for its advice and consent. It is also admitted that the President of the United States would be bound to proceed to frame this compromis in spite of the fact that he believed the question not to be justiciable, because, although he still has a duty to frame the compromis, he is precluded as to the point of justiciability by the decision of the Commission.

But how can the same language preclude the executive in framing the compromis upon the question of justiciability, and at the same time leave the Senate free to reject the compromis on the ground that the question submitted is not justiciable? "It shall be referred to arbitration." Why do these words bind the President and not bind the Senate? And would the language not have been more apt to bind the executive only, if the text had read, for istance, "terms of submission shall be framed and considered in accordance with the provisions of this treaty" ?54

"See colloquy between Senators Bacon and McCumber at the conclusion of Senator McCumber's speech in the Senate, January 22, IgI2. [Congressional Record of that date already referred to.] Senator McCumber also 
If it be said that to send the terms of submission to the Senate and at the same time to preclude the Senate from passing upon the question of justiciability, is to provide for an idle and empty form, ${ }^{55}$ answer might well be made by reference to the large and important powers which will still remain to the Senate. ${ }^{56}$ For instance, the Senate would have the unquestioned power to amend the terms of submission so as to require the substitution for the Hague Tribunal, of such a tribunal as that, for instance, which was agreed upon in the Alaska Boundary Arbitration, consisting of three nationals on each side.

If further illustration of the importance of the functions still left in the Senate be needed, reference might be made to Articles 53 and 54 of the Hague Conventions ${ }^{57}$ which provide that the Hague Tribunal may settle the compromis of arbitration in certain cases, and which expressly recognize that the general power to settle the terms of submission, does not include the power to decide whether a controversy "belongs to the category of disputes which can be submitted to compulsory arbitration" unless the power to decide this latter question is specifically conferred upon the tribunal.

Under these circumstances, with Senators Lodge and Bacon and the other members of the majority of the Senate Committee on Foreign Rerlations insisting that the clause in question means one thing, with Senators Root and Cullom acquiescing in or at least failing to take issue with, this view, with Secretary Knox, the negotiator of the treaty, and Senators Burton and McCumber

argued that the language of the second paragraph of Article III which reads, "the reports of the Commission shall not be regarded as decision of questions or matters so submitted either on the facts or on the law and shall in no way have the character of an arbitral award" applied to cases where "all or all but one of the members of the commission agree and report" that a question is justiciable. He urges that the opening language of the third paragraph, "It is further agreed, however, $* * * * *$ " should be construed as relating back to and modifying the first paragraph of Article III rather than the second paragraph. This ingenious suggestion would, if sound, apparently be decisive; but query, whether it does not do too much violence to the ordinary rules of syntax and construction?

${ }^{*}$ See Senator McCumber's address in the Senate, above referred to.

so See supra.

${ }^{57}$ It will be remembered that these articles are referred to and expressly excluded from incorporation by reference in Article I of the present treaty. 
maintaining a contrary view to which the President appears to have yielded his assent, it seems difficult to refuse to agree with Senator Rayner that "to say the least of it, the last clause of Article III is ambiguous." 58

If this be admitted, it seems difficult for the friends of the treaty to object to the declaratory resolution which Senator Lodge has presented ${ }^{59}$ construing the treaty as to the point in question as it is construed by Secretary Knox, since it may well be assumed that the construction placed upon the treaty by the Secretary of State, is an interpretation acceptable to the governments of Great Britain and France, and that a resolution which merely recites this constructon, will cause no difficulty in the ratification of the treaties by these two countries. ${ }^{00}$

The pertinent portion of Senator Lodge's resolution is as follows :

"Resolved further, That the Senate advise and consent to the ratification of the treaty with the understanding, to be made a part of such ratification, that any joint high commission of inquiry to which shall be referred the question as to whether or not a difference is subject to arbitration under Article $I$ of the treaty, as provided by Article III thereof, the American members of such commission shall be appointed by the President subject to the advice and consent of the Senate, and with the further understanding that the reservation in Article I of the treaty that the special agreement in each case shall be made by the President by and with the advice and consent of the Senate means the concurrence of the Senate in the full exercise of its constitutional powers in respect to every special agreement whether submitted to the Senate as the result of the report of a joint high commission on inquiry under Article III or otherwise." "61

It will be observed that if this resolution of ratification be adopted, it will not only clear up any possible ambiguity as to

\footnotetext{
sa Senate Document above referred to, page 18.

"Such a resolution was originally suggested by Senator Burton in his minority views. Ibid, p. I4.

${ }^{\infty}$ Compare some interesting suggestions as to the undesirability of a situation where' the Executive, but not the Senate, is bound, in Mr. Snow's Article in the University of Pennsylvania Law Review, already referred to, (December, IgII).

is Senate Document 98 , page 25.
} 
the proper construction of the third paragraph of Article III, when taken in connection with the rest of the provisions of the treaty, but it will at the same time entirely remove any constitutional objection based on the ground of an unconstitutional delegation of power on the part of the Senate, and will therefore presumably meet the views of the majority of the Senate Committee on Foreign Relations. ${ }^{62}$

The fourth and fifth articles of the treaty deal with the details of the machinery of the Joint High Commission, and article seven provides for the exchange of ratifications. Article sixth supersedes the existing arbitration treaty of 1908 but continues in force the treaty of January IIth, I909, establishing the International Boundary Commission of the United States and Canada, to which reference has already been made. ${ }^{63}$

The pending arbitration treaty with Great Britain, like all its predecessors, does not go as far as some would like to go. The treaty and the treaty with France have been denounced on the floor of the Senate by a Senator who declared his intention to vote for their adoption as "mere shells, a delusion, a seeming declaration of peace that is wholly ineffectual as a means to that end." ${ }^{64}$ But it must be remembered that the treaty was

E It is true that the Committee notes the suggestion (Sen. Doc. No. 98, 6and Congress, Ist Session, p. 5) that the treaty as at present drawn works an unconstitutional delegation of the powers of the President, and this suggestion would not be met by the proposed resolution of ratification. But it is not supposed that this suggestion would be insisted upon. The limits of the present article do not permit of any detailed discussion of the question of the constitutionality of the treaty as it stands, as construed by the majority of the Senate Committee on Foreign Affairs. It is submitted, however, that upon any construction, the treaty is constitutional. The United States, has negotiated twenty-five arbitration treaties agreeing to submit differences "relating to the interpretation of treaties" to the Hague Tribunal. If this be constitutional is it not constitutional to agree to submit all the questions arising out of the interpretation of any specific convention to arbitration; and if so how can it be unconstitutional to agree to submit the construction of the pending arbitration treaty as to one point to a joint high commission? "Such a submission is not delegating to a Commission power to say what shall be arbitrated; it is merely empowering the Commission to find whether the particular case is one that the President and Senate have said shall be arbitrated." (Senator Root's Minority Report, Ibid, p. 9.) See also, President Taft's various addresses particularly his address at Rochester, N. Y., August 23, I9Ir, and Secretary Knox's Cincinnati Address).

see supra, p.

"Speech of Senator Works in the Senate, Feb. 8, I912, Cong. Rec., vol. 48 , No. 48 , I925, at 1927. 
drafted, and rightly so, in the light of the history of the previous efforts to secure a satisfactory arbitration treaty with England, in view of what has been shown to be impossible as well as what has been thought to be desirable. In both what it says and what it fails to say the treaty pays homage to the past. The serious opposition which it has evoked in the Senate on the part of those who think it goes too far is perhaps the best answer to those who think that nothing has been attempted. The opponents of the treaty should interplead.

The pending treaty, as construed in Senator Lodge's resolution, does not attempt to go as far in some respects, as the OlneyPauncefote treaty of 1897 , although it goes farther in others; but it must be remembered that the Olney-Pauncefote treaty could not secure the advice and consent of the Senate, even after it had been amended almost beyond recognition. "The shots that hit are the shots that count." To propose a treaty too far in advance of public sentiment, as public sentiment appears to be registered in that great deliberative body which the Constitution has associated with the executive in the treaty-making power, would be useless if not hurtful however well-intentioned, whereas the present pending treaty, with perhaps a declaratory resolution making absolutely plain the meaning which is attached to it by its negotiators, appears at this writing in a fair way to become the law of the land. President Cleveland said in submitting the Olney-Pauncefote treaty to the Senate:

"Though the result reached may not meet the views of the advocates of immediate, unlimited, and irrevocable arbitration of all international controversies, it is, nevertheless, confidently believed that the treaty can not fail to be everywhere recognized as making a long step in the right direction, and as embodying a practical working plan by which disputes between the two countries will reach a peaceful adjustment as matter of course and in ordinary routine."

Washington, D. C,

William C. Dennis. 